\title{
顎関節突起下，斜切骨術による下顎前突症の外科的矯正 そついて
}

九州歯科大学第 1 口腔外科教室 (指導 : 平川正輝教授)

巨山 保 - 古賀洋 海

(1968年 8 月 15日 受理)

\section{SURGICAL CORRECTION OF PROGNATHISM BY OBLIQUE SUBCONDYLOTOMY}

\author{
By
}

\author{
Tamotsu KYOYAMA, Hiromi KOGA \\ First Department of Oral Surgery (Chief : Masateru HIRAKAWA) \\ Kyushu Dental College, Kitakyushu, Japan
}

We obtained satisfactory result after surgical correction of prognathism by subcondylotomy on 18 year old girl, who showed tendency of underdevelopment of the maxillar and the prognathism of mandibular as she grew old, after she had accepted the plastic operation of cleft of lip, jaw and palate in infancy and child.

We consider that the obliqe subcodylotomy for correct of the mandibular prognathism is much more efficient in operative procedure, because, it is not only simple on approach, but also safety on the facial nerve or main blood vessel.

は じめ に

いわゆる下影前实症の外科的矯正法として, 上行枝に 対する切骨術は, Horizontal osteotomy, Vertical osteotomy, oblique osteotomy 飞大別される. Horizontal osteotomyは，1907年 BlairがGigli鋸を用いて，経皮的に 上行枝の単純水平切骨を行なった報告をして以来，諸 家 233)455)67788311332339)により応用され推奖されてきた。 ころが，乙の単純水平切骨は，両骨片の接触面が少ない ために, 術後, 骨の癒合が悪く, 開咬を生じやすいなどの 欠点があることなどから，てれらの欠点を補うために， 種々の改良法が考跎されてきた。即ち、Wassumund9) は，切骨線後縁に三角形の骨形を残して骨の重複を計 り，両骨片の接触面を増大している。また，Dingman 10), Caldwel111), Skaloud12) らは, 経口的あるいは経皮 的に切骨を行なった後, 雨骨片を骨縫合して, 術後変位 の防止につとめたと記載している. 更にKazanjian13)は, 経皮的に Bebel cut し, Schuchardt14) は, 経口的に刺
鋸を斜めに使用して切骨を行ない，骨接触面の増大と側 方変位防止を計っている. しかし, 両骨片の接触面の問 題あるいは下顎角の改善が不可能など本法の有する欠点 は避け難い。 Obwegeser 15)16117)は，乙の欠点の改変と して Sagittal splitting osteotomyを行なって, 広い骨 接触面を得るとと屯に，加えて下顎角の改善をなし得た と述べている.

この様に上行枝水平切骨む種々改良されていたけれど あ,一方, Caldwell and Leterman18) らは, 上行枝の Vertical osteotomy を行ない, また Hinds19)20)p Thoma21) らは, Oblique osteotomy を考按して, 水平切骨 の有する問題点を解決しえたと報告した：この様な過程 を経て, 今日では, 下顎前突症の外科的矯正には, 乙れ らの術式が一般に応用される傾向を示している。

今回，私達は，高度の下筫前突症の治療にあたり上行 枝の subcondylar oblique osteotomy を試みたので,と こにその概要を報告する. 
症

例

患者; ○西○恵 18才 웅

初喨；昭和42年 5 月 30 日

主訴; 顔貌の醜形

家族歴；父母，兄妹に特記すべきことは認められな W.

現病歴：右側唇一顥一口蓋裂のために，ブラジルにて 出生直後に口唇形成，また2才頃，口蓋形成手術を受け いずれ奇形治癒したが, 昭和29年に本学付属病院にて 奇形治瘁した口蓋裂および口唇裂の再形成手術を受け た。以後，生長につれて下顎前突が目立ち，咬合異常が 著しくなってきたので, 歯科知正治療を受けつつ, 口腔 外科に紹介され来院した。

現症

全身所見; 体格, 栄養ともに中等度で, 手術を終えた 口唇一顎一口蓋裂以外に外見上他部の奇形を認めない.

局所々見

口腔外所見 ; 右側鼻腔より赤唇に至る口唇形成手術後 の瘵痕が認められる。唇一顎一口蓋裂の先天的奇形を有 しているためか, 上顎の発育が正常の同年配女性に比へ て極めて悪く，それにもかかわらず下顎がむしろ良好な 発育を示しているためか，著しい下顎前突症の形態を呈

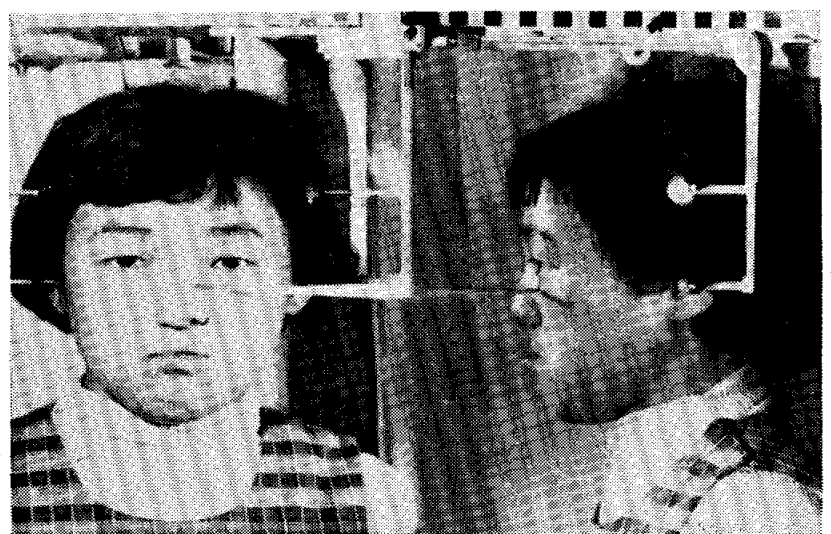

術 前顔貌 写 真

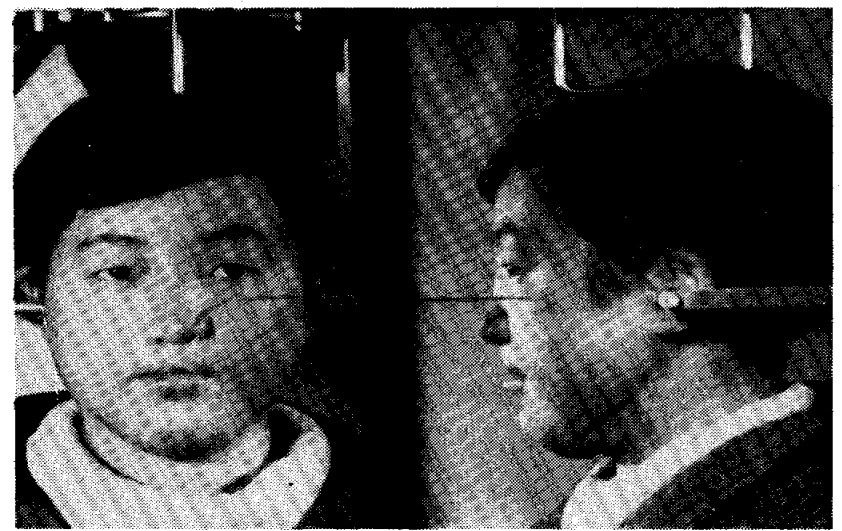

（図1）術後 顔 貌 写 真

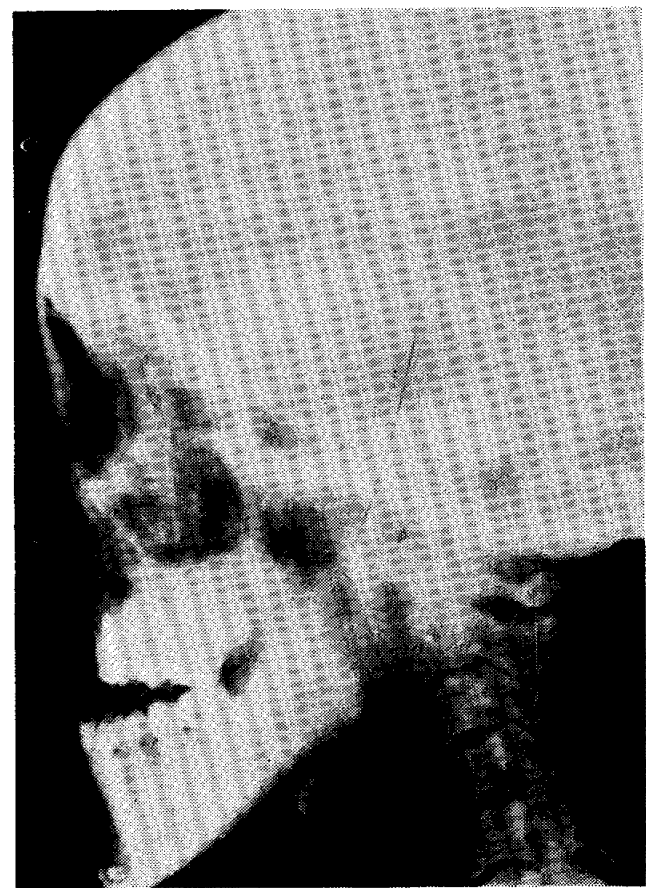

術前側方規格 X線写真

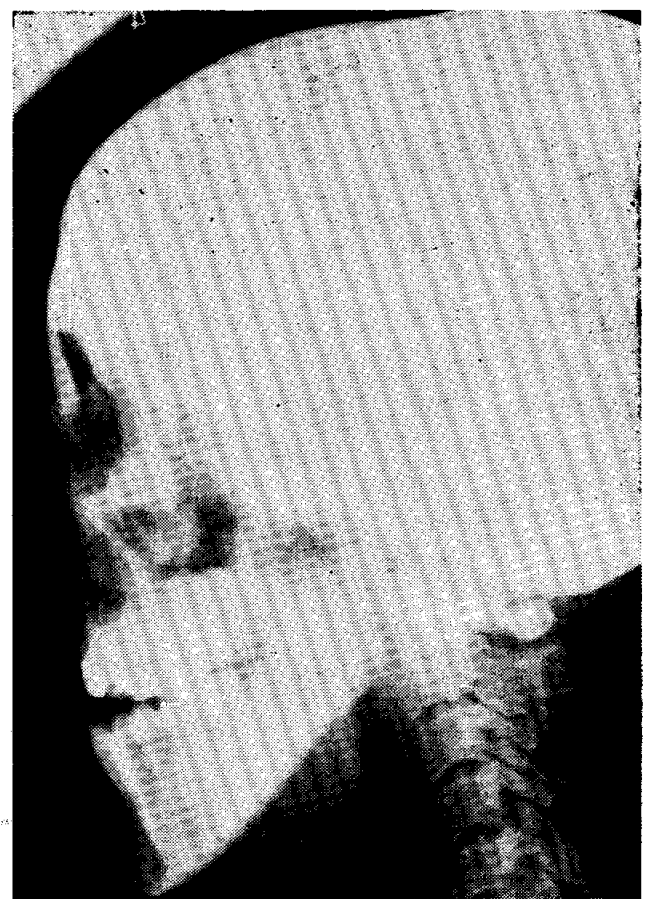

(四 2)

術後側方規格 $\mathrm{X}$ 線写真

している（図3）.

口腔内所見 ; 右側顎一口蓋部に形成手術後の痕跡を認 め，上顎歯牙の配列が極めて不正である．閉口時には雨 側大曰㐘が咬合しているのみで，他の歯牙の咬合は認め られず強度の開口状態を呈している，反対咬合による上 下中切㐘間の距離は，約10mmである.

臨休検査; 赤血球数 $430 \times 10^{4} / \mathrm{mm}^{3}$, 白血球数 $6,600 /$ $\mathrm{mm}^{3}$, 血色素量 86.5\% ( Nach sahli), 出血時間 3 分, 血液型 $\mathrm{B}$ 型，心電図所見，異常は認めない。 


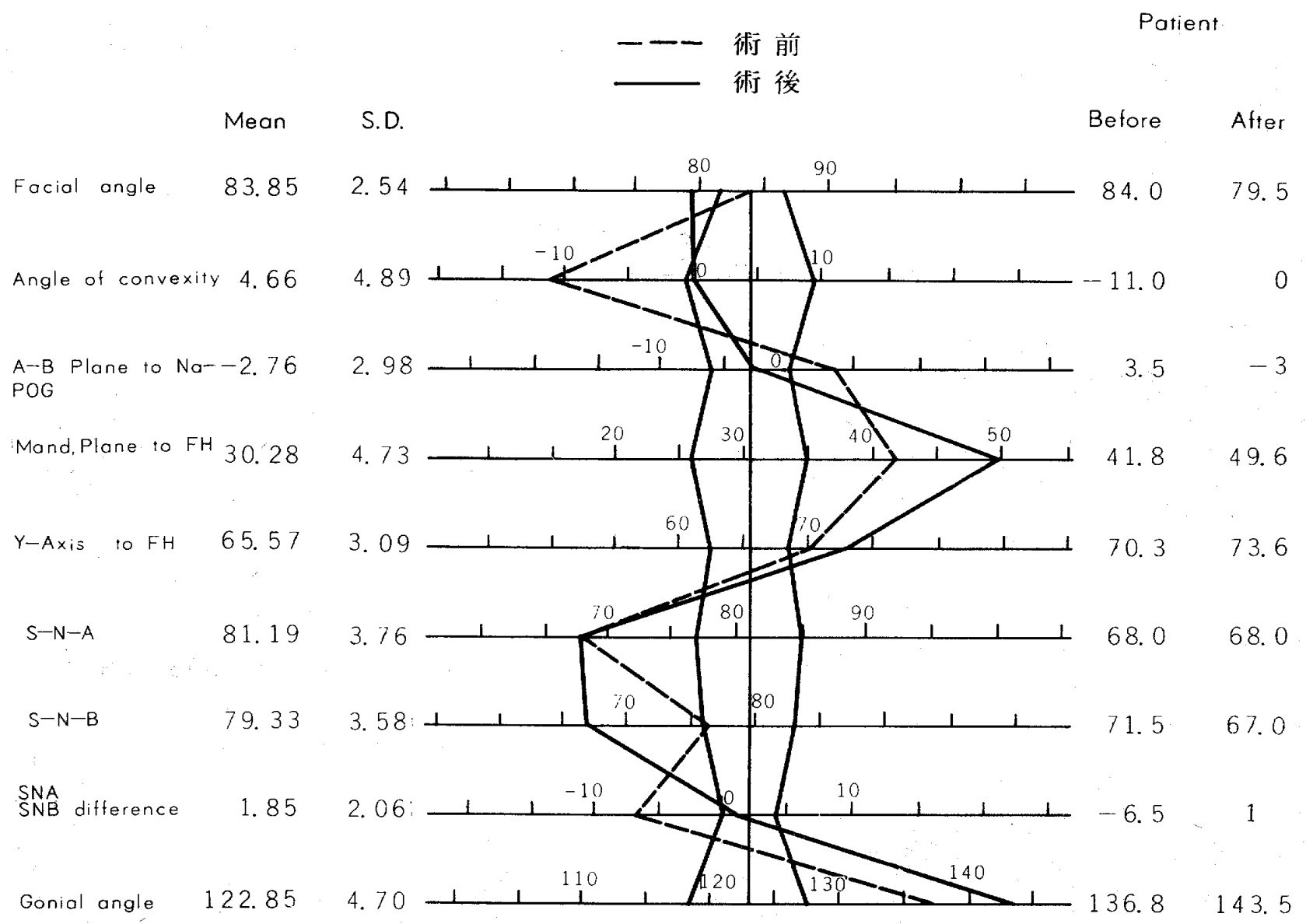

X-Ray Cephalogram Analysis

Method by Downs \& Graber

診断; 仮性下顎前突症

$$
\text { 手 術 の 方 法 }
$$

昭和42年10月27日，半閉鎖循環麻酔のもとに subcondylar obligue osteotomy を行なった。即ち，下颚隅角 部下縁より上行枝後縁におよぶ Natural neck line 亿皮

\section{(図 3 )}

廓切開を加え, 周用組織ならびに咬筋線維を分割剥離 し，上方は下頢切痕部が直視できるまで骨を露出した。

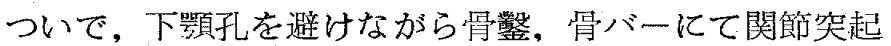
下より隅等部後縁に延長した斜切骨を行ない，乙れを両 側に行なうことにより下顎骨体部を可動性にした。可動
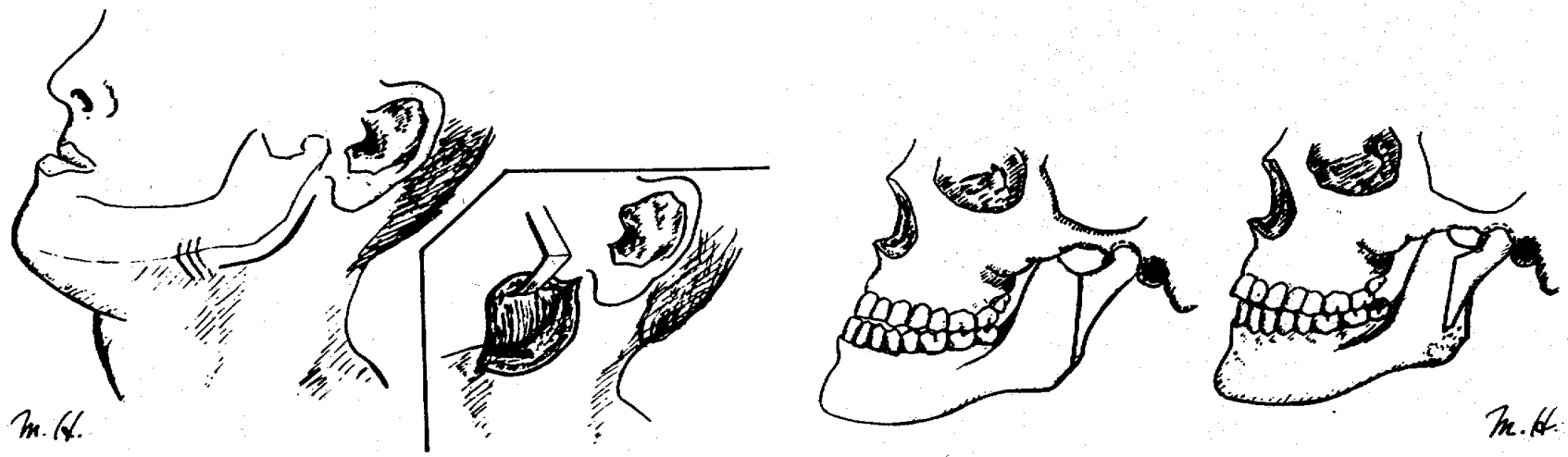

(図,4) 
性となった下顎骨体を後下方に移動し, 術前に予測, 修 正して作製した模型と略々同椂な位置にして骨縫合を行 ない局所の手術を終了した（図４）.

口腔内は顎固定のために有鉤線副子（三内式）を装着 して顎間固定を行なった。

術後は, 感染予防のために, 約 2 週間抗生剂を投与し た。屒およご顔面麻痺も現れることなく，順調な治癒 経過を辿った。顎間固定は, 術後 5 週間で撤去し, 口腔 外保定装置 (願帽) 飞变更した。現在,なお経過観察中 であるが，300日を経過した今日では，2横指半の開口 状態を示し，再発傾问は認められない。

\section{総括ならびに考按}

下顎前突症の外科的钴正法として，上行枝の切骨術 は, 従来, Horizontal osteotomy とその改良法か提唱 され，本邦であ広く採用されてきた，しかし，本法は， 経皮的抬よび経口的にせよ両骨片の接触面が少ないため 骨の癒合が悪く，術後に開口を生じ易く，顎の固定期間 が長く, 更に, 上行枝切断の力向と角度の決定が困難で あり，下顎角は全く改善されないなどの久点を有してい るととが今日諸家 6)1519192223324)25)26)により指摘されてい る。乙れらの欠点を是正するために，上行枝のVertical osteotomy あるいは Obligue osteotomy などの方法が 試みられてきた。

Caldwell and Letterman18)らは，下颚切痕から下颚隅 伤部前方へ至るVertical osteotomy を行ない，乙れによ って両骨片の接触面が広く得られて組織の修復が速く, 顎の固定期間が短縮できるととを強調した．更に強度の 下顎前突症にあっては，下顎角の改善も容易であるなど の多くの利点を挙げている. Trauner and Owegeser 15)16) らは，上行枝の逆L型の Vertical osteotomy を行 ない，同様な利点を有すると報告している。

この様に本法は，水平切骨法にて得られな加った好条 件を具徣しているが, 手術を行なうにあたっては，長い 手術時間を要し18225)，また手術々式が困難19)であるとも 言われている.

一方,1910年 Babcock ${ }^{2}$ が,下顎関節突起下から上行枝 後縁あるいは隅角部上方に至るOblique osteotomy を示 唆して以来, Limberg22), Kosteca27), Schaefer23)らが応 用してきた。そして，近年に至っては，Hinds 19)2J) and Girotti29), Robinson'23), Shira24), Alling25), Thoma21)

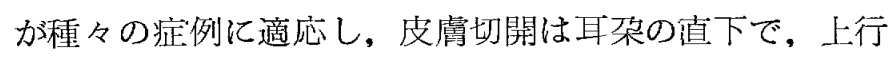
枝の後縁に平行になされるから, 容易に下顎隅角部や下 顎切痕部に接近できるので，手術も簡単に行なわれ，外 部痏痕む小さく目立たないとと，また両骨片の接触面が
增大し，鄂間固定は 6 週間以内に短縮でき，更に顎角の 改善が得られ, 颚間動脈損傷や神経損傷, 術後の開口な ぞを萑起しないなどの利点を述べ，本法を推奨してい る。

以上の如く，上行枝の水平切骨に対する欠䧩を補足す るために Vertical osteotomy および Oblique osteotomy が考按されて，好結果を得ているが，最近では，下颃前 突症の外科的矯正法の動向は, Oblique osteotomy K向 けられている。

吾々も症例の項で記載した如く，高度な下額前突症に 対して, 関節突起下より, 下顎隅角部後縁に至る $\mathrm{Ob}$ lique osteotomy により治療を試みた。とれによってほ ぼ満足な結果を得るととすに，先人す記載しているよう に, 次の諸点が本法の利点であるととを経験した。即 ち，1．特殊な器具を必要とせず，骨鏊，骨バーで容易 に行なえる．2．下䪽角がいく分改善される．3.几唇や 顔面の麻盘を生じない，4．口腔外法で行なうので完全 な無菌状態のもとに実施され，また皮膚切開は，Natural neck line 亿一致してなされるので洀痕はああまり 目立たない，5，骨接触面が広く得られるので，顎間固 定装置は簡単なむのでよく，固定期間も短縮できる.

6. 咬筋線維の分割のみで切骨ができるので，咀嚼筋に ほと九ど障碍を与えない，7．との切断によれば，下顎 冎体部を各方向に移動するととができる等々である，現 段階においては，本疾患の治療に対し，有効な一術式で あると考えられた。しかし，本法が，経皮的手術のため 多かれ少かれ，術後の瘕痕は避けられないととは事実で ある。

\section{おわりに}

1. 今回, 私達は下顎前突症の外科的矯正にあたり, subcondylar oblique osteotomy を試みた.

2.との術式は, 特殊な器具を要せず, 顔面神経や重 要血管の損傷がほとんどなく，しかも，下顎角の多少の 改善ができるので，術後開咬の発生を予防できるなど， 多くの長所を有しているととから現段階においては, 有 効な一術式であると考えられる。

稿を終るに臨み, 御指導を賜った平川正輝教授に深謝 致しますとと屯に Cephalogram analysis 作製に御協力 下さいました矯正学教室樋口幸男講師に厚く御礼申し上 げます。

本論文の要旨は九州歯科学会例会に報告した。

\section{文献}

1. Blair, V.P; Operatin on the jaw-bone and face : Surg., Gynec. and Obst., 4, 67, (1907). 
2. Babcock, w.w. ; The field of deformities of the jaw: D. Items Interest, 32, 439, (1910).

3 . Blair, v. p. and Ivy,R.H. ; Essentials of Oral Surgery, 355, C. V. Mosby Co. (St. Louis), (1923).

4. Kostecka, F.; Die Chirurgie Therapie der Progenie: Zahnarztl. Rundsch, 40, 780, (1931).

5. Hensel, G.C. ; The surgical correction of mandibular protraction, retraction and fractures of mandibular rami : Int. J. Orthodontia and Oral Surg., 23, 814, (1937).

6. Kazanjian, $\mathbf{v}$. H.; The interrelation of dentistry and surgery in treatmemt of deformities of the face and neck: Am. J. Orthodntia and Oral Surg., 27, 10, (1941).

7. Traynham, W. H. ; BiIateral osteotomy of the rami for marked protrution of the lower jaw : J. A. D. A., 31, 305, (1944).

8. Moose, S.M. ; Correction of abnormal mandibular protrution be intraoral operation: 3, 305, (1945).

9. wassumund, M. ; Lehrbuch der proktischen Cirurgie des Mundes und der Kiefer, VoI.I, 245, Meusser-Verlag (Leipaig), (1935).

10. Dingman, R. O. ; Osteomy for the correction of mandibular malrelation of developmental origin: J. Oral Surg., 2, 239, (1944).

11. Caldwell, J. B. ; Text Book of Oral Surgery, ed. 2, 504, The C. V. Mosby Co. (St. Lous). (1964).

12. Skaloud, F. ; Anew surgical method for correcting prognathism of the mandible: Oral Med. and Oral Path., 4, 689, (1951).

13. Kazanjian, V. H. ; The treatment of mandibular prognathism with special reference to edentlous patiants: Oral Surg., Oral Med. and Oral path., 4, 680, (1951).

14. Schuchardt, K. ; Die Chirurgie als Helferin der Kieferorthopädie ; Fortschr. Kieferorthopädie, 15, 11, (1954).

15. Trauner, R. and Obwegeser, H.; Zur Operationstechnik bei der progenie und anderen Unterkieferanomalien : Deutsche Zahn-, Mund-u. Kieferheilkunde, 23, 1, (1955).

16. Trauner, R. and Obwegeser, H.; The surgi- cal correction of mandibilar prognathism and retrognatia with consideration of genioplasty : Oral Surg., Oral Med. and oral Path., 10, 677, (1957).

17, Obwegeser, H.; The indications for surgical correction of mandibular deformity by the sagittal splitting technique: Brit.J. Oral Surg., 1, 157, (1963).

18, Caldwell, J. B. and Letterman, G.S.; Vertical osteotomy in the mandibular rami for correction of prognathism: J. Oral Surg., 12, 185. (1954).

19. Hinds, E. C. ; Surgical correction of acquired mandiblar deformities: Am. J. Orthodontics, 43. 160, (1957).

20. Hinds, E.C.; Correction of prognathism by subcondylar osteotomy : J. Oral Surg., 16, 209, (1958).

21. Thoma, K. H. ; Oblique osteotomy of the mandibular ramus: Oral Surg., Oral Med. and Oral Path., 14, 23, (1961).

22. Limberg, A.; Treatment of open-bite by means of the ascending rami of the mandible: The Dental Cosmos, 67, (1925).

23. Robinson, M. ; Prognathism corrected by open vertical subcondylotomy : J. Oral surg., 16, 215, (1958).

24. Shira, R. B. ; Surgical correction of open bite deformties by oblique sliding osteotomy: J. Oral Surg., Anesth. and Hosp., 19, 275, (1961).

25. Alling, C. C.; Mandibular prognathism : Oral Surg., Oral Med. and Oral path., 14, 3, (1961).

26. Thoma, K. H. ; Oral Surgery, ed. 4. 1129, The Mosby Co. (St. Louis), (1963).

27. Kostecka, F. ; A Contibution to the surgical treatment of open-bite : Int. J. Orthodotia and Dentisiry for Children, 20, 1082, (1934).

28. Schaefer, J. E. ; Correction of malocclusion by surgical interference : Am. J. Orthodontics and Oral Surg., 27, 172, (1941).

29. Hinds, E. C. and Girotti, W.J. ; Vertical subcondylar osteotomy, Areappraisal ; Oral Surg., Oral Med. and Oral Path., 24, 164, (1967).

30. 竹屋隆典他; 下顎前突症に対する外科的矯正法の一 
治験例 : 九州柬会誌, 12巻 1号, (1959).

31. 藤岡幸雄; 下顎前突症に対する外科的矯正法, 特に Kostecha 氏法に就て; 岡山医会誌, 15巻 2 号, (1960).
32. 園山昇他；Progenihaken 使用による下顎前突症の 一手術法について：口外誌, 7 巻 2 号, (1961).

33. 宇賀春雄他; 下顎前突症に抢ける口腔内手術に関す る一考察: 口外誌, 9 巻 1 号, (1963). 